\title{
Nedokončené projekty. Pokus o krizeologickú satiru
}

\author{
Marián Paukov \\ Strojnícka fakulta STU, SR
}

\begin{abstract}
PAUKOV, M.: Unfinished Projects. An Attempt at a Criseological Satire

Philosophica Critica, vol. 7, 2021, no. 1, ISSN 1339-8970, pp. 63-84.
\end{abstract}

The paper offers a satirical view of the crisis in architectural and artistic thought in the $20 \mathrm{~h}$ and anticipating the 21 st century. Using information technology unfinished artistic styles are being finished, their material realizations are being reonstructed. At the same time the contemporary architecture still remains marked by structuralism, deconstructivism and by other city-damaging „initiatives“, as well as by the absence of the creative ones. In conteporary urbanist studies one finds a "tectonic city" carrying a peculiar cultural memory of a "big time" and this trend will not avoid Bratislava, or other Slovak cities. Urbanity understood properiy is being substituted with new information technologies whereas the creation of a new urbanity runs into historicism. The tectonic city, "the city on the palm of the hand" and "smart" pohones in our hands could possibly represent right-brain formations taking place of inflationary left-brain stereotyped spatial material „manifestations“. A new unity should be sought in big and small, in material and also in virtual form of the manifold of the stone cities, information-luminary ones and networked cities.

Keywords: Contemporary philosophy - Urbanism - Smart city - Bratislava

\section{Úvod}

Za prvého krizeológa sa považuje Platón a tiež jeho metafora o „jaskyni nevedomia“ je mierne satirická. Jeho jazyku lepšie porozumeli až teoretici súčasnosti; nešlo natol'ko o vizuálne nevedomie, obmedzenost' nášho poznania zrakovými a vizuálnymi skúsenost'ami, ale hlavne o „akustické“ nevedomie, lebo to je určujúce z pohladu ontogenetického vývoja jednotlivca. 
Ked' historici umenia, ako aj filozof Gilles Deleuze, uvažujú o histórii mal'by, vychádzajú z Egypta a jeho haptických basreliéfov. Nielen metaforicky, ale doslovne povedané - oči vtedy ohmatávali a ruka videla, pričom pozadie a postavy sa nachádzali na jednom „taktilne zvlnenom“ („zvrásnenom“) pláne. Zjednodušene azda možno konštatovat', že tento „nedokončený egyptský projekt" našiel svoje pokračovanie tak v praxi nepuristického, ale emocionálneho avantgardného architektonického a umeleckého myslenia, ako aj v kulturológii 20. storočia (M. Bachtin). Pravomozgové taktilne realizácie sa ukazovali paradoxne vizuálne pôsobivejšie ako „klasické l'avomozgové“, teda „klasické vizualistické demonštrácie“. Múdrost’ jazyka napovedá, že existuje rozdiel medzi niečím pravým a niečím pseudovizuálnym a vizualistickým. Karel Kosík by azda povedal, že existuje svet pseudokonkrétnosti. Tento filozof "to“ demonštroval na diele Franza Kafku. Len neortodoxní teoretici v 60. rokoch 20. storočia konštatovali, že „Kafkov svet“ nejako lepšie „ukázalo“ jeho radiofonické, akusticko-šumové, a nie natol'ko filmové, „vizualistické“ pretlmočenie. V takýchto paradoxoch, nedokončených a „prekrížených projektoch“, sa chceme pohybovat’ v nasledujúcom texte. Medzivojnový art deco ako „alternatívny štýl“ voči modernizmu 20. rokov 20. storočia bol v nami predstavenom duchu spojením racionálneho a emocionálneho funkcionalizmu „s taktilným Egyptom".

Hoci niektorí historici umenia hovoria o viacerých možných (v plnšej miere nerealizovaných) typoch klasickosti, v „bežnej“ historiografii umenia a kultúry vo všeobecnosti prevláda názor, že „klasické zobrazenia“ sa začínajú u Grékov, ich „roztrhnutím“ a „oddialením“ figúry a pozadia, čo išlo ruka $v$ ruke $s$ hypertrofiou svetelnosti a optiky: oko si podrobilo hmat a dotýkanie ako podriadenú oblast'. Nielenže sa oddelilo pozadie od figúry v optickej perspektíve, ale samostatné texty, v úzkom aj širokom slova zmysle, sa vzdialili od mnohorakej farebnosti. Zopakujme: u Grékov bola farebnost' „predznačená“ v haptike.

Táto rozluka sa výrazne prehĺbila v epoche renesancie a „konečne“ spojenie medzi farbou a textom sa prerušilo $v$ epoche osvietenstva 18. storočia, ked' bolo „jasné“, že farba vo fyzikálnom (lepšie povedané: vo fyzikalistickom zmysle) aj v metaforickom význame nebola potrebná na vyjadrenie „zmyslu vecí". Môže sa to zdat' paradoxom, ale obroda renesančného maliarstva tiež bola predznačená plasticko-taktilnými realizáciami.

Podl'a francúzskeho filozofa Gilberta Simondona (opierame sa o jeho interpretáciu v diele petrohradského mediálneho teoretika M. Kurtova), rozluka postavy a pozadia zodpovedá špecializácii „figurálnych funkcií" v technike; komplementárne k týmto aktom sa pozadie dostalo 
do náboženstva. „Figúry“ sa stávajúm technickými, od prostredia abstrahovanými objektmi (prvotnými objektmi zrejme aj v husserlovskom slova zmysle) a pozadie sa univerzalizuje $\mathrm{v}$ božskom prvotnom subjekte. Jan Patočka by povedal: „v božskej osi sveta“.

\section{Nedokončené slohy umenia - dokončovanie v súčasnosti a v budúcnosti}

Ked' sa vysloví barok ako pojem slohového umenia, predstavíme si zvyčajne Berniniho sochy v Ríme (napríklad Extázu sv. Terézie), alebo Borrominiho stavby v tom istom meste. Skúsenejší si však zo sveta umeleckých pamiatok spomenú na Guariniho stavby v Turíne, postavené nielen Guarinim - architektom, ale čo je menej známe, aj tým istým Guarinim teológom a matematikom. V stredoeurópskom kultúrnom okruhu došlo aj k zaujímavej modifikácii baroka - ku kreovaniu barokovej gotiky, stelesnenej napríklad architektom Santinim. Len v prehl'adnejších slohových monografiách sa uvádza aj barok v Rusku, hoci práve v tejto krajine sa barok, ak nie v kvalitatívnom zmysle, tak čo sa týka mohutnosti, rozvinul v určitom zmysle akoby ešte „barokovejšie“ ako to bolo v samotnom baroku v Taliansku. Aj tie najvyhranenejšie slohy z dejín umenia sa vo svetle budúcnosti ukazujú ako nedokončené, nielen v zmysle zámerného „non finito", ako to bolo azda skôr nezámerne u Michelangela, ale aj z vnútornej potreby prevrstvovania, preskupovania a preostrovania umeleckých dominánt, akoby ohnísk, jednotlivých slohov. Práve sofistikované virtuálne technológie, od počítačových hier až po celovečerné hrané alebo animované filmy, umožňujú spravit’ si predstavu aj o „pravej podobe“ tých stavieb, ale aj sôch, ktoré sa nezachovali a ktoré poznáme len z opisov.

Napriek vyššie opísaným procesom, tu zostáva problém: čo bolo podstatou samotnej barokovosti? Protirečenia súčasného umeleckého procesu sa zauzlujú, a to nie do jedného, ale do dvoch "gordických uzlov“. Ako ich pret’at'? Jedným smerom, nazvime to „záhybovým dekonštruktivistickým rozplietaním," sa vydal Gilles Deleuze a postštrukturalisti a s nimi kráčajúci architekti, pričom predbiehajúc, by bolo lepšie napísat' „architekti“. Na druhej strane sa vynára akoby skromnejšia poloha: úsilie o budovanie akejsi novej mikrologickej - „chemickej sústavy“ a zároveň „rovnice“, azda ako analógia k „teórii všetkého“, všetkých druhov a žánrov umenia (na jednej strane rovnice), k celku života (na druhej strane rovnice). Rovnako v zmysle paradoxnosti a zauzlenosti sa to týka aj dialógu medzi umením Východu a umením Západu. Táto téma by si vyžadovala osobitný priestor, preto len parodujúco a zástupne (či humorne - to musí posúdit’ iný) a ilustratívne: Ak sa niekto vyslovil tak, že čerti v pekle budú robit' koláže, tak 
ja som si povedal ani deň bez koláže. ${ }^{1}$ Český spisovatel' Milan Kundera v predhovore monografie o jednom „neznámom“ českom maliarovi napísal: „o čem sa nedá mluvit, musí se namalovat“ (Kundera 2008,13).

V nasledujúcom texte sa odvolám na názory architekta a teoretika Grigorija Revzina, na jeho úsilie o preklenutie filozofie a umenia, pričom postupuje od konkrétnych stavieb až k metafyzike (Revzin 2001). Poukazoval tiež na filozofa Derridu, ktorý kedysi v dialógu s architektom Eisenmanom spochybňoval samotnú možnost' architektúry. Súčasná architektúra, to je už „dekonštrukcia zakrivená“. Je tu na prvý pohlad zjavná podobnost' medzi rotujúcimi stlpmi Borrominiho a súčasnými dekonštruktivistickými výtvormi. Môžeme povedat', že došlo k dialógu a výzve postmodernej a barokovej klasickej architektúry.

Len za posledných 20 rokov sme radikálne reinterpretovali barokové umenie 17. storočia. V interpretácii barokovej tradície až do 70. rokov 20. storočia prevažovalo vnímanie tohto umenia ako plastického javu. 0 haptickom charaktere baroka pochybnosti nevznikali azda aj preto, lebo estetici a filozofi vyhlasovali, že 21. storočie bude haptickým storočím. Táto telesnost' korešpondovala s realizmom flámskych a holandských obrazov barokového maliarstva a s erotizmom barokovej literatúry. Dnes sa situácia zmenila. Barok sa začal traktovat' predovšetkým ako umenie virtuálne, nehmotné, symbolické a matematické. Ústrednými postavami baroka už nie je Bernini a jeho „Extáza svätej Terézie“, ale Leibniz a Descartes. Tento pohlad na barokový sloh sformuloval najmä francúzsky postštrukturalizmus: Gilles Deleuze a Jacques Lacan. Lacan chápal barok ako tzv. „zrkadlovú fázu“ vo vývoji kultúry, zodpovedajúcu „zrkadlovej fáze „ v duševnom vývoji jedinca. Človek si seba uvedomí, ked’ sa pozerá na seba zo stránky, akoby sa videl „v zrkadle“. Inými slovami: celý barokový svet, podla Lacana, je druh „zazrkadlia“.

Prehodnotenie podstaty barokového umenia bolo ešte pred 20. rokmi vel'mi neočakávané, že spočiatku sme ani nechápali, kde sa vyskytujú jeho nové, predtým nepostrehnuté estetické dominanty. Vel'kolepé sochárske výtvory Berniniho alebo Borrominiho architektúry a dokonca aj ohromujúci priestor Balthasara Neumanna sa zdajú natol'ko „telesné“, že máme pocit, ako sa práve tento fakt vôbec nezohl'adnil v novom výklade 17. storočia, výklade, ktorý spolieha hlavne na matematiku, hudbu a literatúru. Ak na jednej strane skutočná baroková architektúra „nespadá“ celkom prirodzene do novej definície, tak na druhej strane sa práve nový sofistikovaný

$1 \quad$ Použil som obal z knihy o mandalách, horizont tvorili ilustrácie z časopisu z výstavy Stredná Európa okolo roku 1000. Obrázok mandaly som rozrezal a pravú polovicu nalepil na l’avú stranu obrazu a lavú polovicu mandaly som zakomponoval na pravú polovicu domal'ovanej koláže. 
postmoderný barok vo vztahu k dekonštruktivistickej architektúre stával názornou demonštráciou „miznutia pocitu telesnosti“. Ukazuje sa, že prehodnotenie baroka, a týka sa to aj iných „dokončených“ slohov umenia v najširšom slova zmysle, je spojené nielen s odhalením nových historických okolností, ale aj s projekciou súčasnej mentálnosti na históriu.

Táto nová jednota sveta, jednota tela a ducha, je pre barok rozhodujúca. Podobný koncepčný postup by mohol byt' dobre aplikovaný na architektonické formy ako také, bez ohl'adu na ich symbolické aspekty. Baroková architektonická forma je hmotná aj nehmotná, materiálna aj iluzórna. Je projektovaná tak, aby ukazovala premenu jedného aspektu do druhého. Architektonické dielo zachytáva veci v procese ich prechodu z pevného stavu do stavu bez tela, ukazuje kolonády, ked' sa začínajú krútit', alebo iné architektonické prvky demonštruje v ich rozpínavosti. Baroková architektúra, to je vlastne cesta z t'ažkého kameňa do sveta abstrakcie matematických formúl Leibniza a Descarta. Nový dekonštruktivistický barok v zásade tiež ukazuje určitú ambivalentnost', ktorá nám neumožňuje jednoznačne tvrdit', či je pred nami architektonické „telo“ alebo prelud. Z hl'adiska genézy ide o dvojakost'. Na jednej strane sú to organomorfné formy, ktoré, akoby sa snažili preniest' do architektúry zákony stavby prirodzenej krajiny, pohybu piesku, zeme, vody, atd'. Na druhej strane, sú to organomorfné formy, zrodené z virtuálnych „vývrtkov“, ktoré vám umožnia vytvárat' trojrozmerné objekty v počítačových programoch a v tomto zmysle nejde ani natol'ko o organickú ako skôr o kybermorfnú formu.

Geneticky je toto protirečenie odstránené pomocou teórie fraktálnej geometrie Benoita Mandelbrota, teórie, v ktorej predložil „matematiku“ popisujúcu morfológiu prírodných foriem aby na jej základe boli vyvinuté počítačové programy, ktoré za pätnást' rokov viedli k vzniku nového architektonického slohu (Mandelbrot 1977). Netreba sa bát' zrejme takéhoto „silného“ pomenovania. Ukazuje sa, že medzi prírodou a počítačovými výtvormi nie je žiaden rozpor: je to príroda inkorporovaná do počítača. Logika nového slohu je očarujúca - fraktálna geometria sa tu nedemonštruje matematickým spôsobom - ako „popis prírody“, ale povedané s renesančným Leonardom, ukazuje „dych prírody samotnej“.

Možno azda povedat', že samotná juxtapozícia, organické a anorganické, prírodné a umelé, tu bolo zrušené. Forma tu v rovnakej miere môže byt' nazvaná ako organická tak aj virtuálna. Pri prvom priblížení sa môžeme tešit', že sa konečne našlo riešenie večnej otázky architektúry, otázky organickej formy: organickost' a virtuálnost' sú synonymá, teda vlastnosti rovnakej morfológie. Na druhej strane môžeme byt' šokovaní tým, že l'udia zabudli, ako rozlišovat' medzi výtvormi prírody a výtvormi virtuálnej fantázie. Žiada sa tu dodat', že v tomto prípade nejde o transformáciu jedného 
aspektu do druhého (ako to bolo uvedené vyššie), ale o neschopnost' rozlišovat' medzi hmotou a virtualitou. Pred nami je tu prúd alebo vír - turbulencia, vzrušujúce architektonické telo, transformované autokatalyticky na svoj obraz a svoju podobu. Rozlišovat' medzi tým, „čo tečie“, čo sú organické a tým, čo sú abstraktné línie, je nemožné jednoznačne.

V skutočnosti je dôležité to, čo sa dekonštruuje. Objektom transformácie sa stáva technogénna abstraktná forma - dajme tomu - sklenený box, rozhraničený na funkčné bunky. Revzin to na svojej internetovej encyklopédii ilustruje na príklade tvorby Normana Fostera. Nie je našim cielom rozoberat' konkrétne stavby. Bez ohl'adu na to, či ide o firemné stavby alebo stavby iného účelu, „narába sa“ tu s internacionálnym dedičstvom architektúry 70. rokov. 20. storočia. Avšak bez nároku na d’alší komentár, len stručne: z architektúry sa môže stat' „písmo“ a týmto „skokom“ chceme naznačit' „pozitívnu“ jednotu kaligrafie a architektúry na Východe, a to v protiklade s oddeleným vývojom týchto „odvetví“2 na Západe.

Z autopsie poznám dekonštruktivistickú architektúru - aj spomínaného Eisenmana v mestečku vedy techniky La Vilette v Paríži. Naozaj tu došlo k spolupráci filozofa Jacqua Derridu a architekta Petra Eisenmana. „Dekonštruktivistické mantry“ sa tu demonštrovali až príliš viditel'ne. V rovnakom čase však dochádzalo aj k zhmotneniu „pôvodného impulzu“: vystavovali sa nerealizované projekty ruských konštruktivistov 20. rokov 20. storočia. Dochádzalo k sút’aži „adaptujúceho a adaptovaného“, avšak s podtextom „označujúce bez označovaného“, čo bolo erbovým heslom určitého anarchistického a vyprázdňujúceho typu postmodernizmu. Klasicizujúca línia postmodernizmu, poukaz na jej potenciálne a v mnohom nenaplnené možnosti - „sväté miesto“ nebýva prázdne - bol tiež podtextovým motívom tohto textu. Táto línia sa natol'ko neusiluje o hru „kto z koho", ale skôr o rovnocennú sút'až minulého a súčasného, bez nulového súčtu. Tak ako sa súkromné vlastníctvo stáva vyprázdneným a archaickým pojmom a nahrádza sa pojmom „prístup do sietí“, tak sa ukazuje, že aj zmateriálnené siete „línie - body - plochy“ v ich aktuálnej demonštrácii, teda architektonické „privlastňovania“ minulého dedičstva, musia počítat’ s nezamýšlaným inverzným procesom, v ktorom sa avantgardizmus môže stat' atavizmom. A ten akoby „posväcoval“ sociálny atavizmus. Je to

2 V Rozhovoroch o humanizme (zachytených aj v rovnomennom texte) v Topolčiankach, v lete 1994, usporiadaných Vysokou školou výtvarných umení a Rakúskym vel'vyslanectvom, som ako prílohu k textu „dodal“ „retikulárny kultúrny strom A. L. Kroebera“. Tiež išlo „o vetvy“. Niečo iné je však operatívna (vedecko-populárna) názornost' a niečo iné je „operatívna názornost’ - realizovaná v architektúre alebo v umení". 
žiadúce? Odpoved' je zložitejšia, lebo nie je také jednoduché odlíšit' potrebné privlastnenia a adaptácie od profesionalistického exhibicionizmu.

\section{Kamenné a zosiet'ované - tektonické optické mesto}

V roku 2019 sme si pripomínali sté výročie od založenia Bauhausu. Bola to nemecká umelecká vzdelávaciu inštitúcia, ktorá v medzivojnovom období poskytovala progresívnu výuku študentom remesiel, umenia a architektúry. Stredná škola umeleckého priemyslu (pôvodne Škola umeleckých remesiel, 1928-1939) bola akýmsi pokračovaním tej nemeckej a aj slovenskej medzivojnovej školy. Reforma vzdelávania je aktuálna aj dnes, ked' sa hovorí o výchove mladých mužov a žien na učňovských školách a ich príprave pre inovatívny priemysel. Ide o nové postavenie remeselníka ako aj stredoškolských a vysokoškolských odborníkov v duchu „nedokončeného projektu“ antického techné. Tvorivost', flexibilita a schopnost' spolupráce by nemali byt' atribútmi len remeselných dielní, ale aj škôl všetkých typov. Tekton a idey Bauhausu, to sú synergetické projekty pre „prítomnostnú budúcnost“".

Ako angličtina, aj slovenčina dobre zachytáva rozdiel medzi historizmom (dejinnostou) a jeho dvojníkom, „zmocnením sa“ historického pohybu v jeho deformovanej podobe - pomocou termínu historicizmus. Práve tieto umelecké školy nás naučili to, že kultivovaná farebnost' (teplé a studené farby) išla ruka ruke s "grafickou taktilnostou“.

Precíznejšie sa voči budúctnostnému historizmu v prvej polovici 20. storočia vyjadroval český historik a kritik umenia František Kovárna, ktorý historizmus „videl“ aj u maliarov, ktorí stvárňovali na prvý pohlad „nehistorické motívy“. ${ }^{3}$ Tento vynikajúci a takmer každodenný glosátor českého a svetového umenia, nebol natol'ko "tradicionalistom“ ako skôr „moderným klasicistom“, pričom je treba podotknút', že nám ide o viaceré podoby klasicizmu, nielen toho, ktorý spájame s antikou, renesanciou a novodobým klasicizmom a neoklasicizmom 19. storočia. Všeobecná poetika mu pomáhala odhal'ovat' napríklad slepé cesty historizujúceho „pomníkového moru“. František Kovárna v medzivojnových rokoch d’aleko, hoci z neradikálnych a moderantných pozícií, predstihol dobu, anticipujúc „tvrdé megalomanské 50. roky“ v Česko-Slovensku. Prirodzene, po roku 1948 „zostalo“ preňho miesto len na kapitalistickom Západe.

a) Polycyklickost' a polyfonickost' kultúrnych cyklov

Aj ked' nepreberieme sugestívnu cyklickú synchronicitu jeho súčasníka Oswalda Spenglera z knihy Zánik Západu (Spengler 2000)ㄹ, podla ktorej

3 Bližšie o tom (Kovárna 1942).

4 Táto a aj iné knihy 0 . Spenglera o technike a civilizácii vyšli v českom preklade. 
sa v modernej dobe pohybujeme v neskoro-antickom, rímskom civilizačnom okruhu a dokonca niektoré fázy rímskej civilizácie sú pred nami, aj tak sa tu pred nami, vynára plotinovská vízia sveta, vzývaná hlavne v umeleckých projektoch. Vel'ký ruský filozof Alexej F. Losev sa pred koncom svojho života sumárne vyjadril, že pre neho najprimeranejšou filozofiou, v individuálnom aj v kozmickom rozmere, je filozofia Plotina.

V slovenských pomeroch sme „neprešli“ - a ked, tak len vo vel'mi skrátenej podobe - cez historickú fázu „iného“, „taktilného klasicizmu“. V architektúre a celkovo vo výtvarnej sfére sme „neprešli“ cez štýl art-deco, štýl, ktorý v sebe okrem kubizujúcich prvkov obsahoval nielen klasicko-antické prvky, ale aj egyptské tvaroslovie. To však nie je najdôležitejšie, lebo práve tento štýl, čiastočne nadväzujúci aj na secesiu, vyzdvihol fenomén architektonického, sochárskeho, ale aj dekoratívno-užitého „medzipriestoru“. Taký americký výtvarník John Steiger dokázal v novinových ilustráciách na jednej novinovej stránke sprítomnit’ v štýle art-deco „celú Ameriku“.

Ak nie Bratislava, tak celé územie Slovenska je z umelecko-historického hladiska polyslohovým priestorom: $\mathrm{k}$ „slohovosti“ prispieva vo vel'kej miere aj geografické prostredie. Ani nie v tak „d’alekej“ minulosti sa Dunaj deltovito spomal'oval práve na miestach Bratislavy; bolo to historické mesto, nielen obklopené karpatským masívom, ale priamo doň vklinené. Architekti v Bratislave, akoby si v nedostatočnej miere uvedomovali, že žáner okien je sebareflexiou samotnej budovy, čo si pravdepodobne najprenikavejšie uvedomovala secesia alebo "slohy“ ešte z obdobia do konca 60. rokov 20. storočia. Ak historizmy a eklektizmy 19. storočia chápali okná ako dvere, secesia a ňou infikovaný modernizmus (teda nie voči nej protikladný, ale skôr ako polovičný modernizmus), oba priamo v štruktúre stavieb tematizovali z interiéru vychádzajúcu „okennost’ okien“. Secesné okná boli akýmisi očami budovy a aj celok bol týmto determinovaný. Ak sa majú rozšírit' priestory v Bratislave na Židovskej ulici, ako „opravit'“ to, čo bolo niekedy „slohovo“ neprípustné? Neprístupné v tom zmysle, že vel'ká čast' ulice je od jedného architekta. Kde je typická malebnost' a pestrost' uličnej fasády?

Predpokladajme, že vel'ké alebo menšie slohy umenia a architektúry mali a majú svoju rétoriku; opät' možno hovorit’ o rétorike longue durée, rétorike prechádzajúcej cez mnohé obdobia. $\mathrm{V}$ takejto perspektíve, napríklad neutrálny minimalizmus (konštruktivizmus alebo neskôr „hravý postmodernizmus"), neboli niečím neutrálnym, pričom, povedané jednoznačnejšie: ten prvý išiel ruka v ruke so sociálnym a kultúrnym maximalizmom a teda „štátotvorným totalitarizmom“. Dnes sa objavujú polemické názory, že ten druhý nás, našu vnútornú a vonkajšiu architektoniku myslenia a emocionálnu sféru, rozleptáva zvnútra. Okrem iného to akosi 
súvisí s tým, že od antiky (s vynechaním stredoveku) a renesancie postupujúci estetizmus mestského prostredia spôsobil, hlavne, v osobnosti Leona Battistu Albertiho, že sa oddelilo projektovania stavieb od ich realizácie. Konzervatívne alebo pesimistické prístupy sa pýtajú: nenastal čas pre „nový stredovek"?

Na chvíl'ku pripust'me, že architektúra je „matkou všetkých umení, ked' na jednej strane „rovnice“ je rozmanitý sociálny a spoločenský život a umenie v interakcii s jeho špecificky „periodickou“ (prírodne sa rozširujúcou) sústavou umenia a na druhej strane „rovnice“ je „celok umenia“ vo vztáahu k jednotlivým druhom a žánrom umenia. Ak nastáva „nerovnica“, v teoretickej reflexii sa to premietlo asymetrickou „dvojicou pojmov“: historizmus kontra historicizmus. Historizmus „rovnice“, to nie sú len historické témy alebo slohové historizujúce eklekticizmy, ale predovšetkým vyrovnaná „bilancia“ života a umenia. Zaznamenáva to akosi múdrost'jazyka, v zmysle možného „riešenia“, a nie „nastolovania problémov“"dutými slovami“.

Slovo a termín synchronizácia sa používa v mnohorakých významoch, často sa vyskytuje v súvislosti s debatou „o synchronizácii ekonomických cyklov“. Termín synchronicita sa zase vyskytuje napríklad vtedy, ked’ je reč „o synchronicite morfogenetických polí“. Zjednodušené povedané, pri vedeckých alebo technických inováciách sa čím d’alej, tým v menšej časovej vzdialenosti, synchronicite, objavujú „tie isté“ objavy alebo vynálezy, avšak najčastejšie na priestorovo odlahlých miestach. Je potom klamlivé porovnávat' napríklad Bratislavu s najbližšími metropolami, lebo práve ide o možnú, aj ked' zatial' skôr potenciálnu synchronicitu so vzdialenejšími metropolami, a predovšetkým s porovnatel'ne vel'kými krajinami (napríklad Dánskom). Pre Bratislavu nie je natol'ko izomorfická Viedeň a Budapešt', ako skôr Kodaň. Kultúrna synchronicita je zložitejší problém nielen plurality navzájom sa vylučujúcich kultúrnych vzorcov, ale predovšetkým, hladaním ,jadra“ prirodzenej kultúrnosti a religióznosti v rôznych kultúrnych a náboženských (európskych aj mimoeurópskych) modeloch, a to hladaním religióznosti v pôvodnom slova zmysle: viazaním.

b) Myslenie nohami alebo myslenie od konca

V súčasnosti nový typ dramaturga, režiséra alebo vrcholového manažéra, mysliaceho „od konca“, zverejní napríklad v blogu svoj, či už umelecký alebo technologický zámer, a spoločne s blogujúcimi hladajú riešenia. Podobne niekedy Henry Ford vynechával niektoré fázy sériovej automobilovej výroby a ponechával to na stredné manažérsko-konštrukčné kádre. Henry Ford bol l'avoruký ${ }^{5}$, v priamom aj v prenesenom kultúrnom zmysle myslel od konca.

5 Kniha o lavorukých v dejinách vyšla v slovenskom preklade (Wright, 2008). 
Dobrá technológia, sa čím d’alej tým viac, stáva meta-technológiou. Revolúcia, ktorá prebehla v internetovej a informačnej agore čaká na svoje technologické pokračovanie. V slovenských kultúrnych kontextoch na konci šest'desiatych rokov zaznievalo heideggerovské „podstatou básnictva je básnenie o podstate básnictva“. Žial', nepokračovalo sa v tom aj v globálnejšom celosvetovom meradle, po roku 1968, ked' sa skončili debaty „o konvergencii“, korešpondujúcej s možnou kultúrnou synchronizáciou odlišných geopolitických priestorov.

V pokračovaní kultúrnej observácie, možno uviest', že aj „ned’aleký“ Salzburg, ktorý zase bol zrejme inšpiráciou pre urbanisticko-architektonické riešenia v Lubl'ane, aj pre v Prahe pôsobiaceho, mimoriadneho slovinského architekta Plečnika. V pozadí toho, že sa uchovalo historické jadro Salzburgu, zo začiatku stála predovšetkým iniciatíva jediného historika umenia Hansa Sedlmayera. Bol známy apelovaním na „zachovanie stredu“, čo bolo odveké pravidlo, harmonizujúce prostredie, ktoré modernizmus v širokom slova zmysle ignoroval. Technokratický modernizmus sa šíril z priemyselných predmestí do historických jadier miest. Ten si podával ruky s rafinovaným staromilstvom. Avšak ruinizácia miest sa môže spriahnút' s pseudokultúrnym sentimentalizmom. Orientácia na retro nemusí korešpondovat s úsilím o zachovanie kultúrnych celkov, a to nielen monumentov alebo ich fragmentov. Vel'ké európske mestá (Drážd’any) rekonštruujú to, čo ešte dlho po druhej svetovej vojne malo slúžit' ako výstraha.

Každého napadne, že dnes naštastie nepodliehame nekontrolovatel'nému demolovaniu miest, ale naopak historické časti si vážime a staráme sa o ne. Áno, turistický ruch, hlavne zisky z neho, tomu zabraňujú. Dnes demolujeme iné dedičstvo: dedičstvo papierovej knihy a knižníc. Kto dnes nejasá nad novými elektronickými knihami, elektronickými vedeckými časopismi prístupnými len pre členov komunity, nad prepisovaním papierových kníh do elektronickej podoby? Čo neviete, že výroba papierových kníh je nákladná? Nie ste za úsporu peňazí? Čo neviete, že papierová kniha zaberá vel’a fyzického priestoru a elektronická nie? Kto protestuje? Knižnice nebudú musiet' už v budúcnosti držat' papierové knihy, budú poskytovat' iba elektronické a svoje usporené priestory budú môct' prenajímat' kaviarňam a butikom a tým získat' viac finančných prostriedkov na nákup nových titulov. A možno v novej dobe romány Dickensa a Huga sa stanú čistou fantastikou, zabudnutím a staré časy sa budú môct' opät' vrátit'.

Ktoré stredoveké mestá poznáme? A nemyslíme tým skanzeny ako Benátky, San Gimignano, Bruggy, Ávila alebo Cáseres ležiaci vedl’a rímskeho skanzenu Mérida. V ktorých mestách je zakomponovaná stredoveká, renesančná, baroková architektúra, architektúra 19. storočia a moderná 
v jednom komplexe a v jednej harmónii? Najviac sa, okrem Ríma, k harmónii blížia nemecké mestá - napríklad Augsburg, Frankfurt nad Mohanom (aj po zdemolovaní počas II. svetovej vojny), alebo Brémy, ale aj iné, napríklad Štokholm. Mestá, ktoré svojej kráse a rozvoju môžu d’akovat' neobmedzeným finančným prostriedkom vtedajších diktátorov. Tí nemali nikdy v dejinách problém získat' dostatok peňazí od poddaných, otrokov alebo dnes obyčajných občanov na svoje monumentálne stavby, paláce, zámky, vidiecke sídla. Mnohí autori, zaoberajúci sa fenoménom mesta nám dávajú príležitost' nazriet' do epochy plnej hýrivosti a frivolnosti. Medzi nimi existujú aj hlasy s pokojnejším akoby „biedermayerovským“ štýlom, takíto autori k mestu pristupujú zase subverzívno expresionistickým štýlom.

Na porovnanie možno uviest' iný prístup k mestu, a to od akademického maliara Dušana Badu. Aj Bada zmenil žáner, prešiel od mal'ovaných granátových ciest $\mathrm{k}$ ich skutočným predobrazom a ich popisom, ktoré ako granátová cesta prebiehali aj cez územie Slovenska a Bratislavy. Badova textácia v kolektíve architektov, urbanistov, archeológov a mnohých iných profesií je literárne nezamenitel'ná a vel'mi presná. ${ }^{6}$

\section{Prelomové obdobia vývoja mestského priestoru}

Pri hladaní mesto-objavitel'ských štýlov môžeme pozorovat' paradox: nezachránia nás nezmyselné teatralizované závody, ale úsilie o hĺbku a celistvost' poznatkov. 0 vzdelanost' v Európe sa spočiatku starali kláštory, ktoré neskoršie transformovali do univerzít. Obidve inštitúcie boli zakladané v pokojnom prostredí mimo mesta s ciel'om vytvorit' vhodné prostredie na štúdium. Dnes sú kláštory a univerzity pohltené mestami a preto aj ich úroveň (pragmatické zameranie na zisk, technika na úkor vzdelania) a význam v spoločnosti náležite upadli.

Poznat' svetové vel'ké aj malé mestá (predmestia vel'kých miest) znamená poznávat' jednak našu budúcnost', jednak našu minulost' „,v tret'om svete“. Estetizmus spočíva práve v miešaní žánrov alebo v skákaní z minulosti do budúcnosti. Moralizmus, antipód estetizmu, zase spočíva bud' v jednostrannom lyrizovanom historicizovaní smerom do minulosti, alebo v nepatričnom dramatizovaní smerom do budúcnosti. Lyrika a dramatika si môžu podávat' ruky a vynechat' takto prepotrebný prozaizmus súčasnosti. Tak isto sa môže sofistikovaná elita spojit’ s nižšími sociálnymi vrstvami a vynechat' nevyhnutný aj inžiniersko-technický a pracovno-remeselný sociálny stred. Postfordistické „malé série“ však môžu byt’ dodávané „zhora“ (k čomu by nemalo dochádzat'), čo vylučuje vertikálne sociálne zmierenie takých alebo onakých morálnych alebo náboženských, či skôr

${ }^{6}$ D. Bada napísal úvod k sérii historicko-projektívnych máp (Bada 2008). 
pseudonáboženských fundamentalizmov. Mestá v pravom slova zmysle boli zakladané, nie predovšetkým ako mestá turistiky, s vychytenými hotelmi a snobistickou „všadebolskou“ manierou správania, ale ako miesta spoločenského styku. Ak obdivujeme mestotvorné iniciativy štátnikov a meštanov, nemali by sme zabúdat' ani na mestoničitel'ské „iniciatívy“ často tých istých predstavitel'ov, ako to bolo už uvedené v prípade haussmannovskeho Paríža a podobných príkladov je vel'ké množstvo.

Synchronizácia času metaforických náhražok agory či už v podobe internetu, facebookov, bloggov a iných elektronických médií, nikdy nenahradí „logiku vecí“. Je biedou, ked' sa „profesionáli“ s takouto logikou, logikou „chýbajúcej tváre“, vyjadrujú o Bratislave, a ked' vlastne to negatívne je pre nich pozitívnym faktorom. Ak aj novinový a architektonický bulvár majú rovnaké etymologické korene, nemalo by to znamenat' znižovanie nadol, ale povyšovanie aj mestotvorných foriem a aristokratizovanie kultúry smerom hore. Ak nejaký politik zvolá, že Slovensko je predovšetkým dedina, mali by sme mu vediet' pohotovo odpovedat', že nejde o dedinu alebo vidiek, ale je to „krajina“ znekultúrňovaná chýbajúcimi mestskými alebo regionálnymi (aj mesto aj vidiek tvoriacimi) iniciatívami.

Preberali sme pojmy synchronizácia, synchronicita v kontexte so sociálnym priestorom a sociálnym časom v európskych i mimoeurópskych mestách. Prejavuje sa to $\mathrm{v}$ aj v kontinuite historických slohov až po internacionálny štýl art-deco v medzivojnovom období. Formy neklasickej klasickosti a zároveň archaizácia neprimeranej kultúrnej a cilivilizačnej asynchronizácie dodávajú nástroje k intenzifikácii synchronizácií, mikrologických žánrov, kultivovaných v makroskopickom urbanizme miest, cez architektúru budov, dekoratívno-užité umenia a grafický design až po najmenšie slovesné, vizuálne alebo pohybovo-taktické žánre. Architektonika vôní miest v pozitívnom zmysle, spolu s ich choreografickým a akustickým obrazom, tiež patrí k novým synchronizujúcim kategóriám, tak ako sa v súvislosti so zeleným mestom a vzorovým mestom budúcnosti, pripomínajú secesné Brémy.

Ak je Brusel jedno z rodísk secesie, a najmä okná secesných (aj bruselských) domov sú sebareflexiou celého domu, „neostáva“ nám tu iné, len znova parodovat' s možnými pikantnými asociáciami: „Secesné okná všetkých krajín v globalizovanom svete, spojte sa!“ Pričom pojem „okná“ možno chápat' v mnohorakých priamych a hlavne v prenesených významoch. „Dolovanie“ v informačno-kultúrnych „dátach“ (v oknách grafických počítačových programov), to akoby azda bola obdoba mumfordovského: mestskost', nie doslova mestá, vznikli pôvodne v baniach, pod zemou, nie na dennom, ale na umelom svetle, svetle podzemných miest. Tiež Slovenská technická univerzita, azda $\mathrm{v}$ duchu kontinuity a jednoty kamenných 
a svetelných miest sa pripája vo svojej predhistórii k slávnemu roku 1762, roku vzniku Baníckej akadémie v Banskej Štiavnici.

Už spomínaný americký výtvarník John Steiger zobrazuje v štýle art-deco americký sen, ktorý v medzivojnovom Česko-Slovensku zaznieval viac v bat'ovsko-americkom Zlíne, ako v internacionálnej Prahe, sen, ktorý sa u nás po socialistickom povojnovom období prerušil v roku 1968.

Aj v pozadí mnohých modernistických smerov sa v tom ich najklasickejšom období prejavovala až egyptská priezračnost', známa z egyptskej nástennej mal'by. Priezračnost'ou sa azda vyznačovali aj mnohé diela slovenskej výtvarnej avantgardy a modernizmu. Nejde však len o ne samé, ale o to, že prostredníctvom umeleckých diel dochádzalo a dochádza k anticipácii budúcej sociálnej reality. V novom svetle sa preto objavia aj slovenské l'udové výšivky práve pre svoju nezvyčajnú diverzitu, čo akoby korešpondovalo s postfordistickými „malými sériami“. Diskusie o „vel'kých televíznych okruhoch", hoci ide aj o súkromné televízie, nemajú zmysel, ak si neuvedomíme, že tak, ako existuje „malý energetický cyklus“, existujú zatial' u nás málo využívané aj „malé televízne okruhy“. Z viacerých strán sa dostávame k informáciám, že zahraniční študenti si jednotlivé vysoké školy vyberajú aj podla toho, ako dostupné sú prednášky pedagógov na internete, čo by teda predbežne mohlo predstavovat' takzvané „malé televízne okruhy“.

Ak dejinné cykly prebiehajú v mierne humornom alebo úsmevnom zmysle, vždy je to lepšie ako asynchrónny rehot alebo vysmievanie protivníka, kde sa často nahrádza argumentácia sexualizovanou terminológiou. $\mathrm{V}$ kultúrnom zmysle sa omnoho viac, ako je to $\mathrm{v}$ bežnom vedomí známe a rozšírené, zjednocuje lyrika s fyzikou a tiež lyrika s dramatikou. Minulostný historizmus si môže podávat' „nečisté ruky“ s budúcnostným futurizmom. „Čisté ruky“, to je úsilie o nové podoby a formy spolužitia $v$ civilizovanej Európe a v civilizovanom svete.

Tak legalita ako aj v narastajúcej miere legitimita, nielen právna a legislatívna zákonnost', ale aj eticko - morálna vyspelost' a demokratickost' verejnej správy v modernej spoločnosti, závisia na dvoch veciach. Najskôr, od schopnosti vládnucej elity, predbežne bez hodnotových znamienok, vytvorit' priestor pre súkromné iniciatívy a verejné kreatívne autonómie pre všetkých občanov. Zjednodušene povedané: „žit’ svoj život slobodne a tvorivo", ale nebránit', ba skôr napomáhat' (radit', podnecovat', byt'mžičlivý a spolutvorivý) aj iným a s inými; sústred’ujeme sa tu na vzdelávanie a výchovu budúceho inžiniera (prostredie, v ktorom pedagogicky pôsobím), „žit' život budúceho bakalára a inžiniera ako umenie a ako umelec“. Po druhé, to, čo musí systematicky, nielen v horizonte volebných (4-5 ročných) období, robit' súčasný (nielen nacionálny) štát, je poskytnutie 
materiálnych podmienok pre realizáciu zásady slobody a spravodlivosti v horizontálnom a vertikálnom „tkanive“ spoločenského bytia. Všetko toto si samozrejme vyžaduje vysokú úroveň hospodárskeho rozvoja.

Tento integrovaný prístup $\mathrm{k}$ inštitúciám verejnej moci, ako to poznáme v sociálnych vedách, sa definuje ako koncept sociálneho štátu, pričom už v úvode treba dodat', že nejde o nacionálny štát, lebo to je práve predmetom (skôr položením otázok, vzhladom na rozsah článku a potrebu dlhodobého interdisciplinárneho a kolektívneho prístupu) našej kritiky: metodologický nacionalizmus kontra transkultúrny, a to nielen európsky a transatlantický, ale aj čínsky, indický, latinskoamerický a africký geografický priestor.

\section{Kto „diriguje“ Bratislavu?}

Kto je dirigentom $\mathrm{v}$ metropole samostatnej Slovenskej republiky? Dovolíme si v tomto texte "laborovat" s hudobnou metaforou, pričom by nemalo íst' len o poukazovanie na „problémy“, ale o demonštrovanie (na príkladoch - poznámkach) a hl'adanie možných riešení. Vynára sa nám jedna spomienka. V nemeckej televízii na začiatku 90. rokov 20. storočia Luigi Colani prehlásil: „Sklamali vrcholní manažéri.“ Colani mal na mysli celú oblast' od designu po ekoprostredie v širokom slova zmysle. Taliansky designer pokračoval: „Kvalitatívne ich pretromfli dirigenti.“ Dirigenti nie v metaforickej, ale v doslovnej rovine významu. Môžeme azda d'alej rozvíjat' „technologickú hru“ v urbanistických a architektonických ekopriestoroch: hráme z jedných nôt, sme všetci „hraní“ z nejakej neviditel'nej skrytej partitúry, hrá sa z mnohých partitúr, alebo sa nejako kombinuje prvé s druhým a tretím s rôznou dominantou na jednotlivých účastníkov? Nejde „náhodou“ o hru s nulovým súčtom? Pri akýkolvvek artefaktoch, „v hre s prírodou“ by vždy malo íst' o nenulový súčet. Tieto artefakty „sa stávajú skutočnými“ len tým, ak sa azda nielen v metaforickom zmysle ustanovuje okolité umelé prostredie ešte viacej „prírodným“ ako „, pôvodnom prírodnom stave."

Ak predsa v 90. rokoch 20. storočia išlo ešte o nejakú polyfonickú heroickost' postavantgardného ducha doby, tak dnes zaznievajú omnoho „monotónnejšie“ a nemúzickejšie hlasy o postupnom „technologickom odcudzovaní l'udstva prejavujúce sa neschopnostou civilizovanej a technologickej vyspelej časti sveta riešit' každodenné problémy l'udí, či už v mestskom alebo nemestskom prostredí. Múdrost' jazyka volá po prirodzenej kultúrnej a politickej zodpovedností „slov-vecí“. Vox populi, vox dei.

Voči reálnému technologickému pokroku $\mathrm{v}$ zjednocujúcom sa kultúrno-civilizačnom svete sa objavuje jeho negatívny mimetický dvojník, 
teda to, čo sa emfaticky označuje ako „kontinuita technokratického sna“. Vyjadruje to napríklad „slovotvorba“: „betonársky sen“, sen pokračujúci cez rôzne spoločensko-ekonomické systémy. Dnes nejde len o prežitie elít, ale o prežitie l'udstva ako celku. Tomu možno výdatnejšie čelit' celosvetovou akciou. „Betonárska lobby“ je len jednou „plošinou“ z možných „tisíc plošín“- „ciel'ov prostriedkov“ aby sa pritlačilo na brzdy, a nie na plyn. „Celosvetová akcia“ by však mala byt’ vyvažovaná tak „vertikálnymi“, ako aj „horizontálnymi“, teda nehierarchizovanými úsiliami. Zjednotenie sveta je predpokladom pre to, aby sa mohli riešit' globálne zmeny, zahrňujúce aj klimatické oteplovanie. Pojem klimatická zmena v tomto kontexte je mimetickým"dvojníkom, idúcim, nadnesene povedané, do pekla. To pre jedných. Iných zase dráždi akoby „postkatastrofický“ pojem klimatické oteplovanie korešpondujúci s hyperobjektmi.

\section{a) Architektonické priestory $v$ historickom zrkadle}

V priebehu moderných dejín vo vztahu k ekopriestoru v širokom slova zmysle možno hovorit' o rôznych alternatívach. Oficiálne dejiny tohto fenoménu sa zvyknú pomenovat’ ako „posvätné dejiny“, teda ako jediné možné. Nemali by sme nechat' rást' „všetky kvety“ na lúke „'udského dobrodružstva", povedané slovami amerického filozofa Alfreda Whiteheada?

Nenazveme to priamo cestami do neba, ale lepšími cestami, ked' necháme okrem prvotného sektoru výroby, všetky energeticko-technologické a tiež „technologicko-informačné kvety“ rásț na kultúrno-civilizačnej lúke a nevytrhávame predbežne „zlú burinu“. Radikalizmus sa môže prejavovat' vel'mi rafinovane aj tak, že jedna alebo druhá názorová skupina „vypáli rybník" protikladného aktéra.

„Neposvätené“ alebo „alternatívne“ dejiny by sa chceli rozíst' so svojimi „silnejšími súrodencami“, s tými, ktoré sa zaštit’ujú tak estetizmom ako aj moralizmom, a paradoxne aj radikálnym „ekologizmom“. Všetko aspoň v minimálnej miere aj vo vztahu s ekopriestorom slovenskej metropoly. Nemožno nepripomenút', že Bratislava sa stále nebuduje ako metropola Slovenska, v zmysle infraštruktúry, z hladiska urbanisticko-architektonického a tiež zo stanoviska kvality bývania, teda ekopriestoru v priamom a kultúrnom zmysle slova (kvalita života).

Vrát'me sa do „zlatého veku“ - dvadsiatych rokov 20. storočia. Na konci týchto rokov v sa Nemecku začali budovat' dial'nice, teda dávno pred nástupom národného socializmu. Predpokladajme, že humanistický „komunikačný sen“ sa v Nemecku neskôr výbojne militarizoval, teda „kontinuita technokratického sna" pokračovala s neblahými dôsledkami pre celý svet.

Zjednodušene povedané, je reč o tom, čo možno popísat', nie ako „pozostatkové mobilizácie vecí" (po horúcich a studených vojnách), ale ako 
určité mnohoraké heterogénne „mierové“ orchestrácie vo vel'kých mestách; v každom vel'kom meste sa inak (s iným rytmom a iným naladením) pohybujú l'udia. Nenachádzame inú lepšie možnost' pre demonštráciu „problémov", ako evokovanie hudobných skladieb Američana Charlesa Ivesa. Ide o prvotné popudy, okrem mnohého iného, k jeho skladbám, rodiacich sa v malebno-farbistom prostredí New Yorku, kde na rozličných miestach hrajúce rozličné hudobné skupiny s osobitými štýlmi vytvárali „harmonicko-disharmonickú" stopu New Yorku. Preložme si to tak, že aj ked' v našom prostredí nemusíme hrat'z jedných nôt, predsa sme zotrvačne ohlušovaní alebo monotónne dirigovaní betonárskymi a inými nekrofilnými snami, skrítka tým, čo by sa Charlesovi Ivesovi zrejme nepáčilo.

Nielen z domácej perspektívy si uvedomujeme, čím vlastne bol kontaminovaný napríklad minimalizmus takzvaných „revolučných“ umeleckých avantgárd z prvej tretiny 20. storočia; neskorý modernizmus pokračoval u nás $\mathrm{v}$ 60.-80. rokoch 20. storočia $\mathrm{v}$ umiernenej podobe, ale aj v ostatnom štvrt'storočí 21 . storočia $v$ nebývalej miere (až na malé výnimky) estetizovaným úšklabkom pseudoarchitektúry a často aj pseudourbanistických štruktúr. V Bratislave sa ukazuje určitý paradox, akoby odobrený termínom: „longue durée“ (dlhé trvanie) používaný francúzskym historikom Fernandom Braudelom, ked' si v nej vel'koryso založená „tereziánska štruktúra" podáva ruky (ponad 19. a 20. storočie) s možným lepším 21. storočím $\mathrm{v}$ priestorovom zmysle. Máme na mysli polovičaté riešenia tak v makro ako aj mikro rozmere.

K tomu prvému: pamät'žánru nám napovedá, že v slovenskej metropole „sa“ v nedostatočnej miere zohl'adňuje toto: nie je to mesto (nemuselo by byt') „pri osudovo rýchlej rieke“. Išlo a mohlo by íst': o „krásavicu - mesto na rieke“. $\mathrm{V}$ „d'alekej“ minulosti sa Dunaj, povedali sme, deltovito spomaloval práve na miestach Bratislavy.

K tomu druhému: architekti v Bratislave akoby si v nedostatočnej miere uvedomovali, že žáner okien je sebareflexiou samotnej budovy, čo si pravdepodobne najprenikavejšie uvedomovala secesia alebo „slohy“, ešte z obdobia do konca 60. rokov 20. storočia.

Bulat Galeyev navrhol taký „periodický systém“ umenia, ktorý, samozrejme, nie je taký prísny ako podla D. Mendelejeva v chémii, ale je dostatočne motivovaný a bohatý na obsah. Galeyev publikoval aj kosoštvorcový diagram. V tejto rozširujúcej sa schéme pripomínajúcej americkú teoretičku Rosalindu Krausovú, s jej rozširujúcimi sa poliami umenia a neumenia,... atd'., je diferenciácia umenia definovaná podla polárnych opozícií „figuratívny - expresívny“ a „vizuálny - zvukový“. 
V konkrétnejšej perspektíve ide o Architektúru ako polyfonickú mnohost' verejných a spoločenských priestorov, tak v exteriéroch ako aj v interiéroch miest, ale aj „architektúru“ tých najmenších druhov a žánrov umenia, mestskej grafiky, vrátane graffiti. Český filozof a spisovatel' Egon Bondy, ktorý žil v Bratislave, sa na začiatku 90. rokov 20. storočia k začínajúcim graffiti $v$ mestských verejných priestoroch vyjadroval s úsmevom a vel'mi pozitívne, akoby „proti prúdu“ verejného diskurzu. Z odstupom času: graffiti áno, ale nie na nevhodných, ale priamo k tomu „pozývajúcich“ prázdnych miestach. Graffiti, akoby si podávali ruky s neosecesnou módou, ked' „ornament nebol zločinom“.

Zahrajme a zacestujme, v čase a priestore, k prírodným ostrovným kultúram, ked' sa k nim pred mnohými desat'ročiami na vel'kých lodiach blížili Európania. Takúto situáciu opisoval, napríklad Claude Lévi-Strauss. Hoci moreplavci videli domorodcov, domorodci vel'ké lode nevideli, lebo im to nič nepripomínalo z ich zážitkového sveta. Vel'ké lode zrejme boli pre nich akési prírodné útvary. Až ked' objavitelia spustili malé lod'ky, ktoré mohli domorodcom pripomínat' ich vlastné „primitívne“ plavidlá, tak až vtedy Európanov spozorovali.

Nežijeme aj my v podobnej „hyperobjektovej situácii“? Prinajmenšom možno pozorovat', že „niečo nie je s kostolným poriadkom“. Sme v tom ponorení a len v malej miere máme kritické zrkadlá, ktoré by nám „našepkávali“, že máme do činenia s atrofiou alebo hypertrofiou tak na strane životných foriem ako aj umenia vcelku. $V$ konečnom dôsledku ide o architektoniku „objektov a subjektov“, v priamom aj paradoxnom slova zmysle, ked’ aj „umelecká a technologická subjektivita je najvyššou formou „prírodnej objektivity".

Vrát'me sa k tej „neviditel'nej lodi“: nie sú to tiež akési hyperobjekty, popísané exaktnejšie aktualizujúco v (Likavčan, Růžička, Janoščík, 2018). Prístup k nim môže byt', zjednodušene povedané, dvojaký: jednak jednohlasný, monologický technologický diskurz, a jednak ten možný polyfónny, ktorý si napríklad z celého vejáru problémov kladie otázku, či protiuhlíková deklarácia je písaná latinkou alebo nejakými inými „ezoterickými“ znakmi.

Pri rozvíjaní motívu: „sprírodňujúcich sa umelých artefaktov“ si vypomôžeme ideami Michaila M. Bachtina ${ }^{7}$ a Vladimira S. Biblera, o polyfónnom románe a umení u prvého a o dialogike u druhého, v opozícii voči „jednohlasným“ technologickým a tiež aj umeleckým sústavam. V pozitívnej rovine: ide o filozoficko-metodologické koncepcie vo vzt'ahu

$7 \quad$ M. Bachtin bol tak na Východe ako aj na Západe v 60. a 70. rokoch 20. storočia považovaný za najvýznamnejšieho odborníka v kulturologickej oblasti. 
$\mathrm{k}$ uvedenému paradigmatickému procesu. $\mathrm{V}$ našom prípade, heslovite pomenované, ako sa $\mathrm{v}$ tomto kontexte vyrovnat' s jednohlasným energetickým, informačným a technologickým diskurzom? Prístupom, ktorý umŕtvuje mestotvorné a ekoaktivity v tom širokom a kultúrotvornom slova zmysle.

Bud'me advocati diaboli a nechajme prehovorit', zjednodušené povedané, jednohlasný diskurz z ich pozície: možno nemáme, v zmysle „kritickej reflexie", ani tie malé lod'ky pôvodných domorodých národov. Ak pripustíme, že euroamerická kultúra je budovaná od svojich počiatkov ako jednota technológie a liturgie, nenapadne nás asociatívne, že samotná „putujúca lod", chrám alebo kostol, v nej „kostolný poriadok“ a tiež „,ivilizačná lod” si ničí aj tie „malé lod'ky“? Tie lod'ky, ktoré sa „zrkadlovo“ odrážali v malých člnkoch domorodých národov. Možno plávajúca lod’ civilizácie zneviditel'ňuje nielen to, čo je v zornom poli „druhých“, možno naše „slepé škvrny" poznania, reflexie a kritiky okolitého prostredia hypertrofovali do celého zorného pola. Všetko to bolo povedané zo stanoviska jednohlasného technologického stanoviska.

Aj ked' to vyznieva radikálne investigatívne, zdá sa nám, že sa vo vyššie prezentovaných názoroch zostavovatelia čiastočne vyhli tomu, aby sa aj filozofická sebareflexia mohla inšpirovat' niečím takým, ako sa javí, metaforicky (a zástupne) povedané, solutions journalism, teda reálnejšou a dedramatizovanou, nie natol'ko melodramickou poetikou.

Nezaškodí pripomenút' si, že umelecká poetika, podobne ako nedokončené a modifikované techné, môže mat’ všeobecnejší dosah aj v informačných a technologických procesoch. Emil Staiger v tejto súvislsti konštatuje: „Zrejme je umělecké dílo dokonalejší, přidržuje-li se spíše středu než obou mezních situací - lyrična, hrozíceho rozplynutím, a dramatična, vedoucího k ustrnutí." (Staiger 1969).

Malá poetologická vsuvka: nakol'ko je v názve textu slovo poetika, tak aspoň v náznaku. Tragikomickost' situácie v našom kontexte môže nastat' vtedy, ked' sa vo všetkom, aj v teoretických reflexiách, hladá akýsi happy end. Ak aj v architektúre a možno všeobecnejšie, $v$ akýchkol'vek umelých artefaktoch, možno hovorit' o „úsmeve vecí", tak „poetologicky“ vol'né zostáva pole satiry. Ved' to je práve oblast' nepokrytej oblasti verejnej kritiky. Je rozdiel medzi kritikou vlastnými tvorcami (a spríbuznenými „kritikmi“) a kritikou nezávislou a demokratickou.

Predsa, dajme „na chvíl'ku“ pravdu (pracovne nazvané) „jednohlasným technológom“. Z ich pohl'adu: nevidíme, že $\mathrm{v}$ globálnom meradle nastáva odklon od modernistického monofunkčného, esteticky segregovaného, mestského verejného a sociálneho priestoru. Od vel'kej lode 
k malému člnu - to je akýsi experimentálny „rámec“ a „pozadie“, pričom v roli jedného alebo druhého (jedných alebo druhých) môže vystupovat' tá najneočakávanejšia konfigurácia vel'kého, stredného a malého kultúrno-technologického „komplexu“ v korelácii s periodicky sa rozširujúcou a „sprírodňujúcou sústavou technológie a umenia“ ako aktualizujúceho sa antického „techné“. Zároveň „malé“ môže nielen usvedčovat' „vel'ké“, ale hlavne starat' sa aj „o vel'ké“.

Z pohl'adu zotrvačného historicizujúceho modernizmu ešte pretrváva orientácia: ak verejný priestor bol garantovaný všetkým, akoby bol „všeobecným“, fakticky sa stal „priestorom nikoho“. Takýto „medzipriestor“ sa často stáva predmetom „privatizácie“ v negatívnom slova zmysle. Nepomýlime sa zrejme, ked' povieme, že verejné priestory typu verejných transportných komunikácií (ako je to „všade vo svete“), akým je napríklad bratislavská autobusová stanica, sa stali predmetom hospodárskej privatizácie. Súkromný vlastník ju predstavuje ako „vec verejnú“, hoci obyvatelia mesta tušia, že môže íst' o budúci neprimeraný „bazár“. Možno dodat', že akýsi „bazár" na nepravom miesto aj preto, že sa zabúda na „dobrý a prerušený architektonický sen“ „mesta ako bazáru“. V mestských verejných priestoroch sa takto, „osudovo“, zmiešava privatizácia so žiadúcou partikularizáciou; dichotómia alebo skôr heterogénnost': všeobecné kontra mnohost' partikulárneho sa zamieňa za verejné kontra privátne.

b) Hyperobjekty: my staviame stavbu, stavba stavia nás.

Tak ako vyššie heslo bolo zneužité „,sorelou“8 - čo by mimochodom mohlo dnes korešpondovat's objektívne orientovanou ontológiou predstavenou vo vyššie menovanom zborníku - tak dnes je už všeobecne známe, že „ruské revolučné avantgardy" (vrátane filmu) hlavne v podobe produkcionizmu, boli akýmsi sovietizovaným - tempo-zrýchlujúcim „tvrdým“ fordizmom, ktorý sa po USA realizoval najskôr v Japonsku, potom v Nemecku, Francúzsku a napokon v Rusku.

Ešte na začiatku 90. rokov 20 storočia sa hovorilo: žit' v New Yorku znamená žit’ najmenej pät' rokov dopredu. Krajiny strednej Európy (okrem Rakúska) si neuvedomili zaujímavý paradox. Hypetrofovaný individualizmus neprichádzal nielen alebo hlavne zo Západu, ale ako to priznávajú samotní „domáci aktéri“, z Východu, teda z geopolitickej postsovietskej sféry.

Všetko zmenili slová! To bolo emblematické, publikované, zvolanie českého výtvarníka a esejistu Emila Fillu po roku 1945, ked’ sa vrátil z koncentračného tábora, a ešte bol pred nami rok 1948. Po roku 1948 už vznikali heslá „o stavbách, ktoré budujú nás“, hoci pred našimi oča mi sa ničili „stavby“ v širokom prenesenom a kultúrne-civilizačnom slova zmysle.

$8 \quad$ Ironická skratka pre socialistický realizmus. 


\section{Miesto záveru : „Vidiet’ ušami“ - cesta od zamračeného tvaru k usmievajúcej sa „tvári“ mesta}

Z doterajšieho možno predbežne konštatovat': Riešenia nie sú „videné očami“, ako skôr zachytávané „otvorenými ušami“. Možno to nebude vel'ká smelost', ak berieme do úvahy, že voči investigatívnemu žurnalizmu „vystupuje" solutions journalism; tak hypoteticky predložíme: vizualizácia stojí voči nedocenenej „akusticite“, teda „Zvukovej stope“ miest.

Múzy idú v sprievode (pohlad akoby prevažne zvonku), tak dnes sa to prejavuje (zvnútorneným pohladom), ako osobitná starostlivost' jedného, dajme tomu, toho najmenšieho žánru umenia, o „vel'ký žáner“, napríklad o architektúru a urbanizmus. V konečnom dôsledku ide o pozitívnu analógiu voči atrofii alebo hypetrofii mnohorakých kultúrno-civilizačných „žánrov života samotného". V dnešnej dobe ide aj o polyfónickost’ miestnych dialektov (žánrov) aj v rámci prevládajúcej angličtiny ako latiny lingua franca, teda možného globálnejšieho vplyvu napríklad frankofónnej, nemeckej a trebárs aj slovanskej „intonačnej kultúry“ na „celosvetovú kultúrno-civilizačnú polyfónickost' doby“, zasahujúcu tak život ako aj umenie.

Pravda, platí to vtedy, ak nastáva neprimeraná inflácia akýchkolvek vizualizácií-exteriérov alebo interiérov moderných, globálne a kultúrne zosiet'ovaných miest. Avšak treba mat' na pamäti, že čím viac je západná spoločnost' závislá na jedinej infraštruktúre, či už energetickej alebo informačne-zosiet’ovanej, tak tým je táto megaspoločnost' zranitel'nejšia. Zranitel'nejšia aj $\mathrm{v}$ čisto vizuálnom a ekologickom slova zmysle. Ide tu o akýsi samoorganizujúci „chaos mesta“ (so zelenou a vodnou komponentou), ktorý má negatívny protipól vo vizuálnom a formovo „historizujúco recyklovanom" prostredí.

V rámci rozohrávania pluralitných „,technologických hier“, „hier s nenulovým súčtom“, dajme nižšie priestor jednému typickému názoru. S poetickou licenciou by sme ho mohli pomenovat' „satirical solutions“. Zostáva otvorenou otázkou, či korešponduje s paradigmou: „winer - winer“.

Filozof Jan Patočka sa vyjadril, že 20. storočie so svojimi rozpormi je pravdou 19. storočia. Neplatí niečo podobné, metaforicky povedané, aj pre našu mestskú oblast'? Nemohla by byt' potom pravdou Smartcity, „pravda lesa“? Samozrejme, zatial' v d'aleko metaforickom zmysle. Naozaj len v metaforickom význame? Povedané s teoretikom médií Marshalom Mc Luhanom: pravdou zosietovaných miest je pravda globálnej dediny. Vybavme si tú starenku a sme pri rozprávkovom diskurze, ked' najprv sa niečo (roztaté telá) potrelo mŕtvou a až potom živou vodou. Bodaj by platilo to, čo v rozprávke: mestá sa najprv umŕtvujú akousi mŕtvou vodou 
kolektívneho architektonického nevedomia alebo skôr bezvedomia a potom nastáva čas ich oživovania.

Ked' sa pozrieme na minulé avantgardy: Nenájdeme tam, napríklad to, že hrany jedného (aj architektonického) smeru, tam boli „obrusované“ úplne protichodným smerom? Umelecký nizozemský neoplasticizmus De Stijl v prvých desat'ročiach 20. storočia "tajne“ komunikoval s absolútne protichodným dadaizmom. Deje sa niečo podobné aj dnes? Pritom ide o mnohost' sociálneho vynaliezavania, a to nielen pojmov, ale v samotnej sociálnej skutočnosti, „tehotnej“ netriviálnymi alternatívami.

Nie je úsmevné, že ked’ sa priblížime k nizozemským susedom, k flámskemu regiónu v rámci Belgicka, sme zrazu v inom svete? Bolo to dané aj inštitucionálnymi („konzervatívnymi“) opatreniami zhruba od konca 30. rokov 20. storočia, ked' sa tam kládol dôraz na individuálny dom. Z nevýhody sa stala akási výhoda. Zjednodušene povedané, heroická moderna v okolitých „vel'kých krajinách“ sa rozišla - pomenujme to obrazne poeticky - s "textualistickým secesionizmom". Vo flámskej mestskej a vidieckej architektúre sa zrodil „patchwork“; „heroické stavby“ sa objavovali tak na vidieku ako aj v menších mestských sídlach. Dialo sa to akoby v protiklade k zaužívanej urbánnosti, teda ako patchwork aj vo väčších verejných mestských priestoroch. Celá mestská a nemestská megaštruktúra sa stávala niečím udomácneným, a to prostredníctvom aktivít menších alebo väčších spoločenstiev. Tomu zodpovedalo meradlo, kompozícia a akési „emocionálne naladenie“ týchto realizácií. Stojíme tvárou tvár k novej technologickej výzve, internetu vecí, ked' automobilový priemysel môže byt' mierne prevalcovaný vel'kými informačno-technologickými firmami a na ne sa viažucimi autonómnymi elektromobilmi a „ekologicky“ a energeticky nefosílnymi producentmi. To znamená: všetkým, čo má prívlastok Smart.

V Západných krajinách a tiež v Japonsku sa nielen projektujú, ale aj realizujú vízie o prepojení budov, ktoré stoja a autami, ktoré sa hýbu. S tým ide ruka v ruke spoločné využívanie vecí (nielen dopravných prostriedkov), čo je zároveň výzva k oživeniu dediny, k postupnému vymiznutiu rozdielov medzi mestskými a dedinskými regiónmi.

Všetko toto by mohlo viest' k novej kvalite života: namiesto času stráveného za volantom, využívanie „zvyšného času“ k regenerácii a vzdelávaniu. Avšak v protiklade k pionierskym „všetko internetizujúcim“ časom, akoby rušiacim "miesto v práci“ a „miesto doma“, sa dnes zdôrazňuje ich vyvažujúca komplementarita dôležitá pre l'udské zdravi a, duševnú pohodu. 
V súčasných urbanistických štúdiách sa pripomína „tektonické mesto" “9. Ide pritom o celkom vel'ké „tektonické masívy“ s osobitnou kultúrnou pamätou „vel'kého času“ - so skrytou perspektívou možnej Bratislavy, ale aj iných miest Slovenska. Mestskost'v pravom slova zmysle si podáva ruky s novými informačnými technológiami. Aj pri koncipovaní mestskosti sa naráža na historicizmus. Tektonické mesto, „mesto na dlani“, a „chytré“ mobily $\mathrm{v}$ rukách by azda mohli byt', povedané kulturologicky, pravomozgovými útvarmi, namiesto inflačných l'avomozgových stereotypných priestorovo-hmotných „manifestácií“. Vo vel'kom aj v malom a najmenšom, $v$ hmotnej aj vo virtuálnej podobe mnohorakých kamenných a informačno-svetelných a zosiet'ovaných miest.

Text vznikol ako súčast' riešenia vedeckého projektu VEGA č. 2/0156/18 Fenomenologická noematika a perspektívy fenomenológie II.

\section{Literatúra}

BADA, D. (2008): Úvod. In: Bratislava. Minulost'a budúcnost'. Prelomové obdobia vývoja mestského priestoru. Bratislava: Občianske združenie Bratislavské ostrovy. KOVÁRNA, F. (1942):Historisace a historismus.In: Kritický měsíčník.(5)2.

KUNDERA, M. (2008): 0 čem se nedá mluvit, musí se namalovat. In: Dubroka ip: Groteskno v sexualite i jinde (obrazy). Praha: CFC atelier, s. 13.

LIKAVČAN, L., RŮŽIČKA, J., JANOŠČÍK, V. (2018): Mysl v terénu. Filosofický realismus v 21. století. Praha: Akademie výtvarných umění.

REVZIN, G. (2001): Projekt klasika. Internet: Web. 8. Okt. 2020. <http://www.projectclassica.ru/index.htm>.

PAUKOV, M. (2019): Tektonické mestá a nové informačné technológie: divergentné fragmenty z väčšieho celku. In: Fraktál, 2, 118 - 125.

SPENGLER, O. (2000): Zánik Západu. Praha: Academia.

STAIGER, E. (1969): Základní pojmy poetiky. Praha: Československý spisovatel. WRIGHT, E (2008): Slávni l'aváci v dejinách. Bratislava: Fortuna libri.

\section{Mgr. Marián Paukov, CSc.}

Centrum jazykov a športu

Strojnícka fakulta STU

nám. Slobody 17

81106 Bratislava

9 Bližšie o tom (Paukov 2019). 